\title{
POSTOPERATIVE RECOVERY OF THE METACARPAL V FRACTURE BY USING KINESIOTHERAPY RESOURCES
}

\author{
Rață Elena ${ }^{1 *}$ \\ Benedek Florian² \\ 1,2 “Ştefan cel Mare" University of Suceava
}

Key words: means, patient, recovery, trauma

\begin{abstract}
The problem of traumas that occur at hand level isone of continuing importance because of thelarge and constant number of cases that require medication, from the easiest to the more complex (surgery). This study intends to demonstrate and show the importance of kinesiotherapy and hydro-kinesiology program in the process of the recovery of the metacarpal $\mathrm{V}$ fracture. The means used by kinesiotherapy and hydrokinesiotherapy are capable to reduce and eliminate the symptoms and aftermath of fractures.The initial and final evaluation represent imperative components in the implementation of a recovery plan. Kinesiotherapy and hydro-kinesiotherapy can restore the normal functions of the disabled member.
\end{abstract}

\section{Introduction}

The problem of traumas that occur at hand level is one of continuing importance because of the large and constant number of cases that require medication, from the easiest to the more complex (surgery).

The hand, which is an indispensable organ as well as a typically human one, is always subjected to frequent traumas being used in a wide range of working situations (household accidents, traffic, industrial or agricultural accidents) and has thus brought about a new specific medical branch called "Hand surgery".

Because of its shape, structure and importance every trauma caused at hand level must not be neglected, on the contrary, it should be considered a medical emergency, a circumstantial intervention being absolutely necessary in order to establish a most accurate precise and fast diagnosis, all of it with the aim of a speedy and total recovery. (Albu, Vlad, \& Albu, 2004).

The hand traumatology is common (approximately $40 \%$ of fracture cases); the majority of cases are treated easily without any complications. However, 
some (metacarpal bones fractures particularly) require specialized treatment to restore a complete functionality of the hand.

Considering the fact that we cannot perform any activity without using our hands the high risk of producing injury at this level should not terrify us (Raveica, 2006).

Metacarpal bones fractures occur very frequently, mostly in sports activities which involve body contact or in sports activities with ahigh risk of falling (football, rugby, basketball, cycling, athletics, etc.) (Benedek, 2009)

Traumas and hand fractures must be treated with more attention, as the final result of the healing process depends on the fracture type, the delay in dealing with the injury and the final recovery plan (Sbenghe, 1987).

\section{Material and methods}

It is supposed that with anadequate kinetic recovery plan, the life of the people who suffered a trauma at the level of the metacarpal bones can return to normal, sometimes by simply performing physical exercises consciously, correctly and under close observation.

The purpose of this study is to demonstrate the importance of the kinetic recovery program of metacarpal $\mathrm{V}$ fractures.

The realisation of this study had as a subject a male person aged 22, from Suceava County.

The recovery kinetic program was carried out at the Natation and Kinesiotherapy Complex within the "Ștefan cel Mare" University in Suceava, between 10.03.2016 - 09.06.2016.

General information on the patient: Name: F.M., professional athlete (boxing), 22 years old, male. Diagnosis: metacarpal V fracture of the right hand. Clinical investigations: pain in the metacarpal bones area with irradiance to right hand fingers; swelling, grip weakness in the right hand, loss of movement amplitude at the level of the correspondent fingers (IV, V).

Triggering factors: collision, stress, technical mistakes of training. Laboratory investigation: EKG, ECO, RX, others. Surgery treatment: on 12.02.2016 there was performed an open reduction and an osteosynthesis with 2 brooches. Cast immobilisation of the right digital ante brachial palmar. Favourable evolution and medicinal treatment.

Initial evaluation- Setting an efficient recovery protocol was possible only following a complex and efficient initial evaluation. This stage assumed the evaluation of the general state of the subject, of his articular mobility at the hand level, of strength, of sensibility and ability of the hand. In order to achieve this it was necessary that the physical exam and the articular and muscular balance be applied. Along with the evaluation of these parameters we aimed to follow the physical state and the nutritional status of the subject.

VAS scale - the subjective pain of the sufferer The application of the scale offers us information on the way in which the subject perceives pain. That way we can observe the eventual disturbance of their sensibility. 


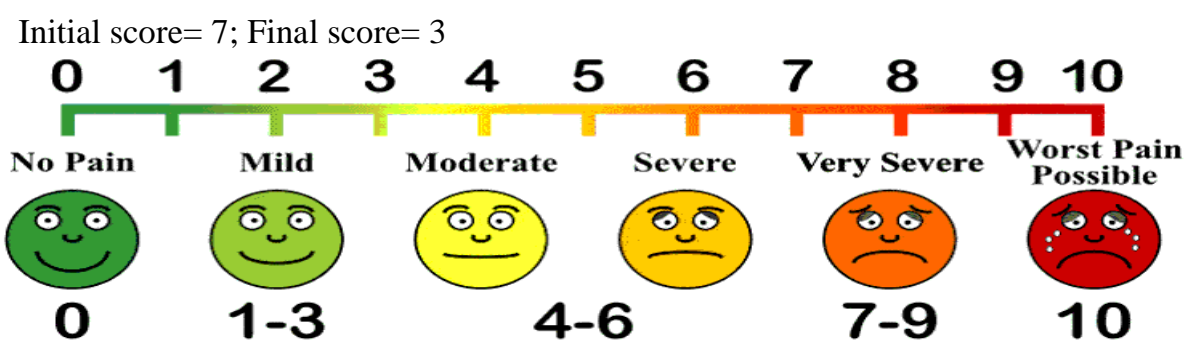

Figure 1. Image of VAS scale https://ro.pinterest.com/pin

We notice that the pain felt by the patient at the initial evaluation decreased very much (approximately by 5 points), experiencing pain only in the moments of intense and long efforts.

Articular balance- performed with the help of goniometer

The achievement of the articular balance using the goniometer shows with precision the degree of movement that the subject is capable to realise.

Table 1 The articular balance of the fist performed with the help of goniometer

\begin{tabular}{|c|c|c|c|c|c|}
\hline \multirow{2}{*}{$\begin{array}{l}\text { Measured } \\
\text { Segment }\end{array}$} & \multirow[b]{2}{*}{$\begin{array}{c}\text { Motion } \\
\text { measurement }\end{array}$} & \multicolumn{2}{|c|}{ INITIAL TEST } & \multicolumn{2}{|c|}{ FINAL TEST } \\
\hline & & $\begin{array}{l}\text { Right } \\
\text { hand }\end{array}$ & Left hand & $\begin{array}{l}\text { Right } \\
\text { hand }\end{array}$ & Left hand \\
\hline \multirow{4}{*}{ Fist } & Flexion & $70^{\circ}$ & $90^{\circ}$ & $90^{\circ}$ & $90^{\circ}$ \\
\hline & Extension & $100^{\circ}$ & $170^{\circ}$ & $165^{\circ}$ & $170^{\circ}$ \\
\hline & $\begin{array}{l}\text { Radical } \\
\text { inclination }\end{array}$ & $15^{\circ}$ & $30^{\circ}$ & $20^{\circ}$ & $20^{\circ}$ \\
\hline & Cubit inclination & $20^{\circ}$ & $45^{\circ}$ & $45^{\circ}$ & $45^{\circ}$ \\
\hline
\end{tabular}

Table 2 The articular balance of the fingers

\begin{tabular}{|c|c|c|c|c|c|c|c|c|c|c|c|}
\hline \multirow{3}{*}{$\begin{array}{l}\text { Measured } \\
\text { Segment }\end{array}$} & \multirow{3}{*}{$\begin{array}{c}\text { Motion } \\
\text { measurement }\end{array}$} & \multicolumn{5}{|c|}{ Right hand } & \multicolumn{5}{|c|}{ Right hand } \\
\hline & & \multicolumn{5}{|c|}{$\begin{array}{c}\text { Finger } \\
\text { INITIAL TEST }\end{array}$} & \multicolumn{5}{|c|}{$\begin{array}{c}\text { Finger } \\
\text { FINAL TEST }\end{array}$} \\
\hline & & I & II & III & IV & $\mathrm{V}$ & I & II & III & IV & $\mathrm{V}$ \\
\hline \multirow{2}{*}{ Finger } & Flexion & 70 & 70 & 70 & 50 & 40 & 70 & 70 & 70 & 70 & 70 \\
\hline & Extension & 40 & 40 & 40 & 35 & 20 & 40 & 40 & 40 & 40 & 40 \\
\hline
\end{tabular}

Muscular balance - done by application of weight with the help of the dynamometer. Using the muscular balance we observe the state of the musculature and force. 
Table 3 The muscular balance of the fist achieved with the help of opposition from the examiner

\begin{tabular}{|c|c|c|c|c|c|}
\hline $\begin{array}{l}\text { Measured } \\
\text { Segment }\end{array}$ & $\begin{array}{l}\text { Motion } \\
\text { measurement }\end{array}$ & $\begin{array}{l}\text { Right } \\
\text { hand } \\
\end{array}$ & $\begin{array}{r}\text { Left } \\
\text { hand }\end{array}$ & $\begin{array}{l}\text { Right } \\
\text { hand } \\
\end{array}$ & $\begin{array}{l}\text { Left } \\
\text { hand }\end{array}$ \\
\hline \multirow{4}{*}{ Fist } & Flexion & F4 & F5 & F5 & F5 \\
\hline & Extension & F4 & F5 & F5 & F5 \\
\hline & $\begin{array}{l}\text { Radical } \\
\text { inclination }\end{array}$ & F4 & F5 & F5 & F5 \\
\hline & Cubit inclination & F4 & F5 & F5 & F5 \\
\hline
\end{tabular}

Table 4 The evaluation of force with the help of the dynamometer

\begin{tabular}{|c|c|c|c|c|}
\hline \multirow{2}{*}{$\begin{array}{c}\text { Difficulty } \\
\text { level }\end{array}$} & \multicolumn{2}{|c|}{ INITIAL TEST } & \multicolumn{2}{c|}{ FINAL TEST } \\
\cline { 2 - 5 } & Right hand & Left hand & Right hand & Left hand \\
\hline I & 5 & 25 & 25 & 30 \\
\hline II & 5 & 20 & 20 & 25 \\
\hline III & 5 & 25 & 20 & 30 \\
\hline
\end{tabular}

Table 5 The score achieved applying different types of gripping

\begin{tabular}{|c|c|c|c|c|c|c|c|c|c|c|}
\hline \multirow{4}{*}{ Type of gripping } & \multicolumn{10}{|c|}{ Score achieved $=56$} \\
\hline & \multicolumn{5}{|c|}{$\begin{array}{c}\text { Right hand } \\
\text { INITIAL TEST }\end{array}$} & \multicolumn{5}{|c|}{$\begin{array}{c}\text { Right hand } \\
\text { FINAL TEST }\end{array}$} \\
\hline & \multicolumn{10}{|c|}{ Fingers involved in gripping } \\
\hline & $\mathrm{I}$ & II & III & IV & $\mathrm{V}$ & $\mathrm{I}$ & II & III & IV & $\mathrm{V}$ \\
\hline $\begin{array}{l}\text { Terminal } \\
\text { (between the top of the thumb } \\
\text { and the top of each finger) }\end{array}$ & 1 & 1 & 1 & 1 & 1 & 1 & 1 & 1 & 1 & 1 \\
\hline $\begin{array}{l}\text { Subterminal } \\
\text { (between the "pulp" of the } \\
\text { thumband the "pulp" of } \\
\text { another finger) }\end{array}$ & 1 & 1 & 1 & 1 & 0 & 1 & 1 & 1 & 1 & 1 \\
\hline $\begin{array}{l}\text { Subtermino-lateral } \\
\text { (between the“pulp" of the } \\
\text { thumband the lateral part of } \\
\text { another finger) }\end{array}$ & 1 & 1 & 1 & 1 & 0 & 1 & 1 & 1 & 1 & 1 \\
\hline $\begin{array}{l}\text { Thumb-digito-palmar (between } \\
\text { palm and the last four fingers) }\end{array}$ & 1 & 1 & 1 & 1 & 0 & 1 & 1 & 1 & 1 & 1 \\
\hline $\begin{array}{l}\text { Opposition digito-palmar } \\
\text { (The last four fingers and the } \\
\text { palm) }\end{array}$ & 1 & 1 & 1 & 1 & 0 & 1 & 1 & 1 & 1 & 1 \\
\hline $\begin{array}{l}\text { Latero-lateral } \\
\text { (the side faces of the fingers) }\end{array}$ & 1 & 1 & 1 & 1 & 1 & 1 & 1 & 1 & 1 & 1 \\
\hline
\end{tabular}


In Tab. 4 one can notice the increase of force in both the affected hand and the healthy one. The muscle force registered an increase of 15 points in the right hand and approximately 5 points in the left hand.

In Tab. 5 one can notice the difficulty in making various types of gripping with the $\mathrm{V}$ finger as well as removing this problem and restoring the initial ability of work to final evaluation.

The recovery plan took place on a period of three months, during which the sessions of recovery took place 5 days a week in the kinesiotherapy laboratory. For the other two days the subject was taught how and motivated to continue the exercises of kinesiotherapy alone at home.

In the case of the analytical heating we used exercises representing physiological movements of all body segments.

A number of exercises were used to meet the intended objectives in the recovery plan; they were performed progressively from the point of view of their intensity and occurrence, and once the diminishing of symptoms was achieved they increased.

The exercises used during the recovery were accomplished using positions of the most convenient (sitting)

\begin{tabular}{|c|c|c|}
\hline \multicolumn{3}{|c|}{ RECOVERY PLAN OF METACARPAL V FRACTURE } \\
\hline CONTENT & MEANS & DOSAGE \\
\hline $\begin{array}{l}\text { OBJECTIVES } \\
\text { - } \text { reducing the } \\
\text { - } \text { reducing the } \\
\text { - } \text { maintaining } \\
\text { - removing the } \\
\text { - reducing fing } \\
\text { - increasing the } \\
\text { - restoring the } \\
\text { - the achievem } \\
\text { - restoration of } \\
\text { - reintegration } \\
\text { - improvement }\end{array}$ & $\begin{array}{l}\text { legree of pain until its total disappearance } \\
\text { legree of inflammation until its total disappearance } \\
\text { he existent function at the beginning of the program } \\
\text { physical and psychical stress of the patient } \\
\text { er sensitivity } \\
\text { motion amplitude in the fist and fingers } \\
\text { revious muscle strength } \\
\text { nt of an accurate reflex of the hand and fingers } \\
\text { hand functionality, of coordination among fingers and of a } \\
\text { n the social environment and workplace } \\
\text { and increase of the subject's quality of life }\end{array}$ & ability \\
\hline $\begin{array}{lr}\text { Exercises } & \text { for } \\
\text { increasing } & \text { the } \\
\text { mobility } & \text { in } \\
\text { motion } & \end{array}$ & $\begin{array}{l}\text { - from the sitting on a chair position, arms relaxed, the } \\
\text { therapist mobilizes passively every articulation of the } \\
\text { fist and fingers (one starts distally from the phalanges } \\
\text { and one ends proximally at the level of the carpal } \\
\text { bones); } \\
\text { - from the sitting on a chair position, arms relaxed, one } \\
\text { mobilizes actively-passively every articulation of the } \\
\text { fist and hand; } \\
\text { - from the sitting on a chair position, arms relaxed, the } \\
\text { subject mobilizes actively every articulation of the } \\
\text { fingers and fist (the therapist supervises permanently } \\
\text { the technique of execution); } \\
\text { - from the sitting on a chair position, arms relaxed }\end{array}$ & \begin{tabular}{l|l} 
e & $3 x$ \\
e & \\
s & \\
l & \\
e & \\
e & \\
e & \\
e & \\
$y$ &
\end{tabular} \\
\hline
\end{tabular}




\begin{tabular}{|c|c|c|}
\hline & $\begin{array}{l}\text { elbows against the torso, palms oriented upwards, } \\
\text { thumb touching each top of the other four fingers; } \\
\text { - from the sitting on a chair position, arms relaxed } \\
\text { elbows against the torso, palms face each other, } \\
\text { touching the correspondent fingers from the other } \\
\text { hand; } \\
\text { - from the sitting on a chair position, arms relaxed, the } \\
\text { therapist mobilizes passively each articulation of the } \\
\text { fingers and fist (one starts distally from the phalanges } \\
\text { and one ends proximally at the level of the carpal } \\
\text { bones); } \\
\text { - from the sitting on a chair position, arms relaxed, one } \\
\text { mobilizes actively-passively every articulation of the } \\
\text { fingers and fist; } \\
\text { - from the sitting on a chair position, arms relaxed, the } \\
\text { subject mobilizes actively every articulation of the } \\
\text { fingers and fist (the therapist supervises permanently } \\
\text { the technique of execution); } \\
\text { - from the sitting on a chair position, arms relaxed } \\
\text { elbows against the torso, palms oriented upwards, } \\
\text { thumb touching each top of the other four fingers; } \\
\text { - from the sitting on a chair position, arms relaxed } \\
\text { elbows against the torso, palms face each other, } \\
\text { touching the correspondent fingers from the other } \\
\text { hand; } \\
\text { - from the sitting on a chair position, arms relaxed } \\
\text { elbows against the torso, palms joined the subject } \\
\text { performs the abduction and adduction simultaneously } \\
\text { with the radial and cubital inclination movement of } \\
\text { the fingers; } \\
\text { thekabbat diagonals for the superior members, flexion } \\
\text { and extension. }\end{array}$ & \\
\hline $\begin{array}{l}\text { Exercises of } \\
\text { regaining the } \\
\text { strength }\end{array}$ & $\begin{array}{l}\text { - fromthe sitting on a chair position, arms relaxed } \\
\text { elbows against the torso, palms oriented upwards with } \\
\text { the fingers stretched, the subject performs a flexion } \\
\text { movement against resistance from the therapist; } \\
\text { - from the sitting on a chair position, arms relaxed } \\
\text { elbows against the torso, palms oriented downwards } \\
\text { with the fingers stretched, the subject carries out an } \\
\text { extension of hand flexion against resistance from the } \\
\text { therapist; } \\
\text { - from the sitting on a chair position, arms relaxed } \\
\text { elbows against the torso, the palm oriented on the side } \\
\text { with fingers stretched, the subject carries out a } \\
\text { radial/cubital movement of inclination of the hand } \\
\text { against resistance from the therapist; } \\
\text { - from the sitting on a chair position, arms stretched } \\
\text { with the palms in supination, one executes a flexion }\end{array}$ & $2 x$ \\
\hline
\end{tabular}




\begin{tabular}{|c|c|c|}
\hline & $\begin{array}{l}\text { and extension of fingers holding a sponge ball in the } \\
\text { palm; } \\
\text { - from the sitting on a chair position, arms relaxed } \\
\text { elbows against the torso , palms oriented upwards, } \\
\text { holding a towel in both hands; one tries to grip onto } \\
\text { the towel maintaining the position for a few seconds; } \\
\text { - from the sitting on a chair position, arms against the } \\
\text { body having a rubber bar (or a towel) one tries to } \\
\text { "squeeze" it while maintaining the final positions; } \\
\text { - from the standing slightly apart position, facing the } \\
\text { espalier and having an elastic band in the palm one } \\
\text { executes a triple flexion movement of the superior } \\
\text { member followed by its extension (forearm wrist } \\
\text { flexion, forearm arm flexion and arm flexion). }\end{array}$ & \\
\hline $\begin{array}{l}\text { Exercises for } \\
\text { re-education of } \\
\text { ability }\end{array}$ & $\begin{array}{l}\text { - from the sitting on a chair position, elbows placed on } \\
\text { the table, palms in supination, the subject executes } \\
\text { movements of gripping; } \\
\text { - from the sitting on a chair position, arms pointing } \\
\text { forward the subject carries out movements of gripping } \\
\text { while catching various objects and maintaining them } \\
\text { for } 5 \text { seconds; } \\
\text { - from the facing the wall position, oriented towards the } \\
\text { "Canadian plate" the subject executes movements of } \\
\text { gripping at the same time with the pulling, holding or } \\
\text { tying of various objects; } \\
\text { - from the facing the table position, the subject carries in } \\
\text { the affected hand various objects from the table into a } \\
\text { chest. }\end{array}$ & $4 x$ \\
\hline $\begin{array}{l}\text { Electro- } \\
\text { therapy }\end{array}$ & $\begin{array}{l}\text { - in order to fight the existence of pain as well as } \\
\text { inflammation and to ensure the kinesiotherapy } \\
\text { exercises a stronger intensity we used a series of } \\
\text { electric currents; } \\
\text { - TENS and Diadynamic currents were used; } \\
\text { - TENS current (trans cutaneous electrical nerve } \\
\text { stimulation) was used for the purpose of diminishing } \\
\text { pain, being effective in the post traumatic cases, the } \\
\text { intensity of the current being oscillating according to } \\
\text { the physical state of the subject; } \\
\text { - Diadynamic Long Period current(LP) was used for its } \\
\text { role of controlling the joint stiffness installed during } \\
\text { immobilization. At the same time this type of current } \\
\text { brought about an analgesic and myorelaxant effect of a } \\
\text { moderate intensity at the palm level. }\end{array}$ & $\begin{array}{l}10 \\
\text { minutes }\end{array}$ \\
\hline
\end{tabular}

The exercises used played an important role in the recovery of a certain functional quality of the hand as well as in re-educating and getting the hand used to performing daily tasks and its particular activities. 


\section{Results and discussions}

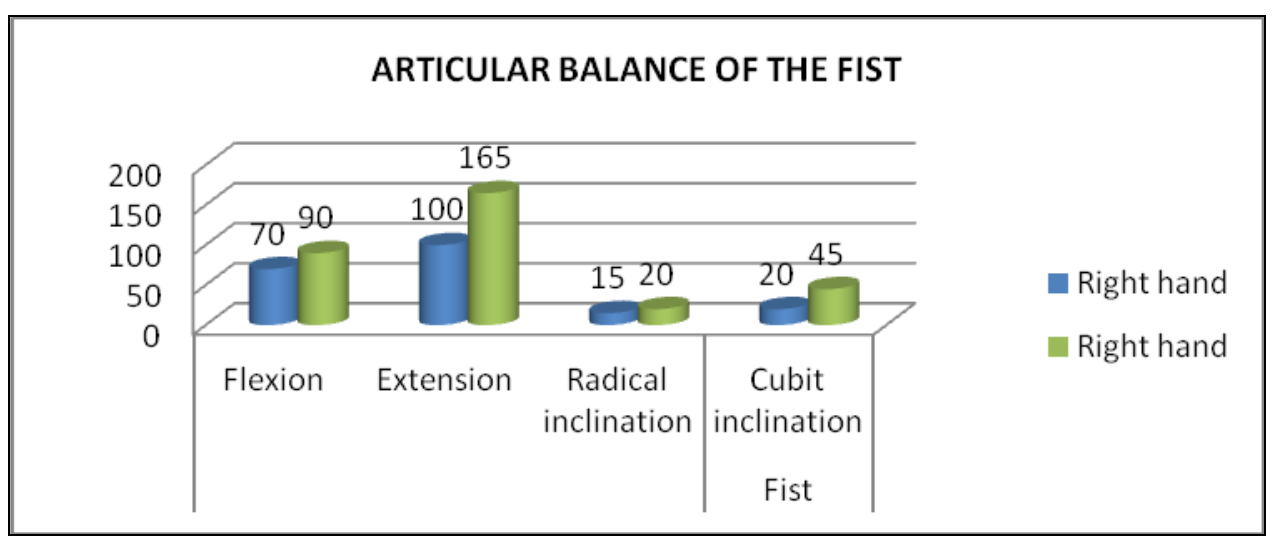

Figure 1. The results obtained after applying the articular balance at fist level

It is clear that the amplitude of the reduced movement of the right fist has grown, its values being very close to the normal ones noted in the left fist. In the case of the left fist, the normal values registered no oscillation and the growth of the amplitude of the movement was noticeable in the case of the cubital inclination movement.

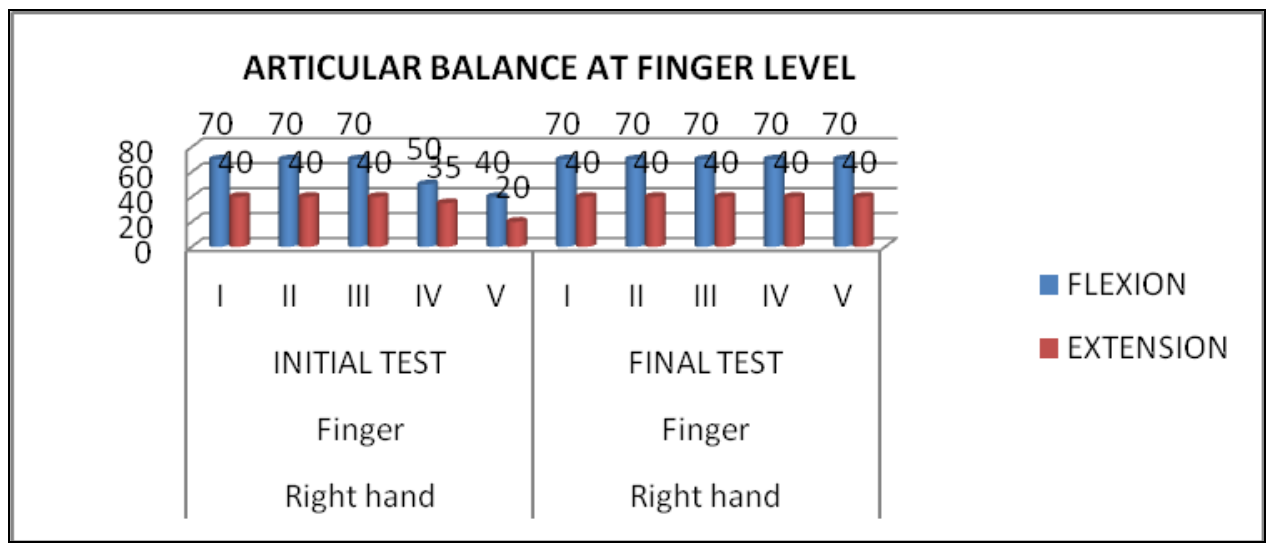

Figure 2. The results obtained after applying the articular balance at finger level

An increase in the muscular strength of the right hand is perceived in all movements (from 4 to 5) and thus, its force becomes normal and equal to that of the left hand. 


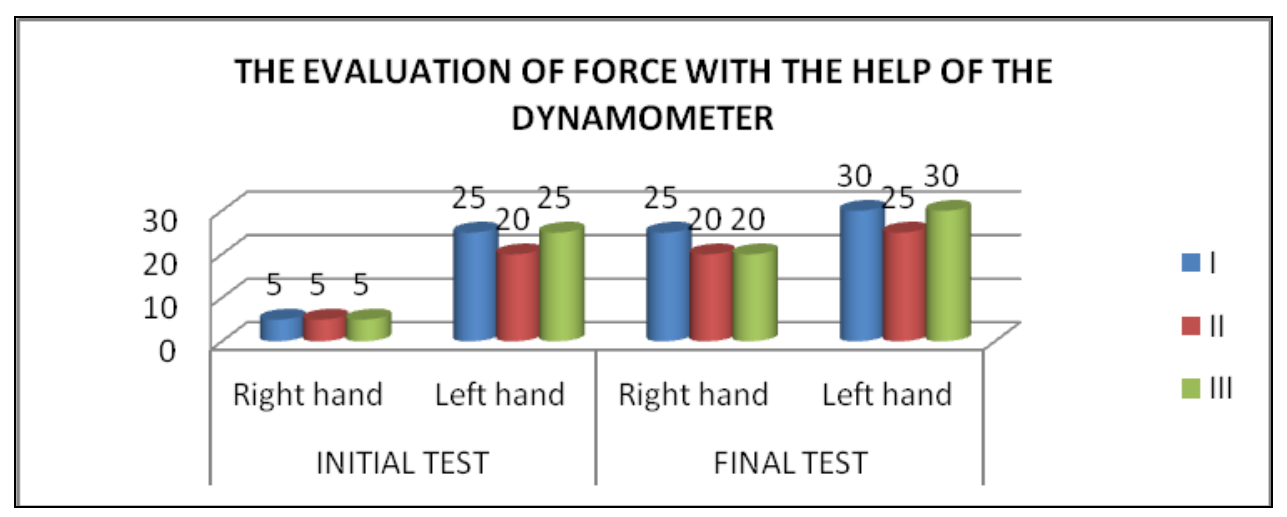

Figure 3. The results obtained after applying the muscular balance at the fist level with the help of the dynamometer

There is an increase in the force registered with the help of the spring dynamometer.

By using the spring dynamometer the palmar force was possible to be measured from three different positions, by opening and closing in the handlebars. The levels had different degrees of difficulty, as a result the force used to handle the dynamometer in level I was more intense, decreasing towards the IIIrd level.

\section{Conclusions}

- The hypothesis was confirmed.

- This paper may be used to carry out an elaborate study on this type of trauma.

- The excellent collaboration of the patient with his kinesiotherapist is an essential factor for a successful recovery.

- A thorough information of the patients, their motivation, conscious work and confidence are the ideals that a kinesiotherapist must strive for.

- Home therapy, carrying on the recovery process and protecting the injured area for a longer period (6months approximately) are necessary steps for maintaining the expected results.

\section{References}

1. ALBU, C., VLAD, T.L., ALBU, A. (2004). Kinetoterapia pasivă, Iaşi: Polirom;

2. BENEDEK, F. (2009). Biomecanica, Iaşi: Polirom;

3. RAVEICA G. (2006). Indrumar de lucrări practice de anatomie, Bacău: EduSoft;

4. SBENGHE, T. (1987). Kinetoterapia profilactică, terapeutică și de recuperare, Bucureşti: Medicală;

5. https://ro.pinterest.com/pin/357332551656748778/. 


\title{
RECUPERAREA UTILIZÂND MIJ LOACELE DIN KINETOTERAPIE A FRACTURII DE METACARPIAN V POSTOPERATOR
}

\author{
Raţă Elena ${ }^{1}$ \\ Benedek Florian² \\ 1,2Universitatea „Stefan cel Mare” din Suceava, România
}

Cuvinte cheie: mijloace, pacient, recuperare, traumatism

\section{Rezumat}

Problema traumatismelor ce survin la nivelul mâinii este una de continuă importanță datorită numărului mare și continuu de cazuri ce necesită îngrijiri de la cele mai simple până la cele mai complexe (intervenții chirurgicale). Prezentul studiu își propune să demonstreze și să arate importanţa programului de kinetoterapie şi hidrokinetoterapie în recuperarea fracturilor de metacarpian V. Mijloacele pe care kinetoterapia şi hidrokinetoterapia le utilizează sunt capabile de a reduce și de a elimina simptomele și urmările fracturilor. Evaluarea inițială și finală reprezintă componente necesare în aplicarea unui program de recuperare. Kinetoterapia şi Hidrokinetoterapia poate reda funcționalitatea normală a membrului afectat.

\section{Introducere}

Problema traumatismelor ce survin la nivelul mâinii este una de continuă importanță datorită numărului mare și continuu de cazuri ce necesită îngrijiri de la cele mai simple până la cele mai complexe (intervenții chirurgicale).

Mâna organ indispensabili specific totodată omului prin prisma traumatismelor dese la care este supusă în meserii dintre cele mai variate (accidente casnice, rutiere, industriale sau din agricultură) a dat naștere unei ramuri medicale specifice și anume „Chirurgia mâinii”.

Datorită formei, structurii și importanței sale orice traumatism produs la nivelul mâinii nu trebuie neglijat ciconsiderat o urgență medicală, fiind necesară o intervenție amănunțită în vederea stabilirii unui diagnostic cât mai corect, precis și rapid, totul în scopul unei recuperări rapide și totale. (Albu, Vlad, \& Albu, 2004).

Traumatologia mâinii este una des întâlnită (aproximativ 40\% din cazurile de fracturi); majoritatea acestora sunt tratate ușor fără complicații însă unele (fracturile oaselor metacarpiene în special) necesită tratament de specialitate pentru a reda o funcționare cât mai complectă a mâinii.

Având în vedere faptul că nu putem efectua aproape nicio altă activitate fără a ne folosi și mâinile nu trebuie să ne sperie riscul crescut de producere a leziunilor la acest nivel. (Raveica, 2006).

Fracturile oaselor metacarpiene survin foarte des, cu precădere în practicarea sporturilor de contact sau din practicarea sporturilor în care riscul de 
a cădea este unul mai ridicat (fotbal, rugby, baschet, ciclism, alergare, etc.) (Benedek, 2009).

Traumatismele și fracturile mâinii trebuie tratate cu mai multă atenție rezultatul final al procesului de vindecare depinzând de tipul fracturii, timpul de intervenție asupra problemei și programul recuperator final (Sbenghe, 1987).

\section{Material si metode}

Scopul lucrării constă în demonstrarea și importanța programului kinetic în recuperarea fracturilor de metacarpian V.Realizarea acestui studiu a avut ca si subiect o persoană de sex masculin cu vârsta de 22 de ani din Județul Suceava.

Ipoteza cercetării

Se presupune că prin recuperarea unui program kinetic adecvat, viața persoanelor ce au suferit un traumatism la nivelul oaselor metacarpiene poate reveni la normal, uneori doar prin efectuarea exercițiilor fizice în mod conștient, corect și subt atentă supraveghere.

Programul kinetic recuperator s-a realizat la Complexul de Natatie și Kinetoterapie din cadrul Universității "Ștefan cel Mare" din Suceava, în perioada 10.03.2016 - 09.06.2016.

Date generale ale pacientului: Nume: F.M., sportiv de performanță (box), vârstă 22 ani, sex masculin. Diagnostic: fractură metacarpian V mâna dreaptă. Investigații clinice: durere în zona oaselor metacarpiene cu iradiere spre degete la nivelul mâinii drepte; tumefacție, pierderi ale forței la nivelul mâinii drepte, pierderi ale amplitudinii de mișcare de la nivelul degetelor corespondente (IV, V).

Factori declanșatori: lovire, stress greșeli tehnice de antrenament. Investigații paraclinice: EKG, ECO, RX, altele.

Tratament chirurgical:la data de 12.02.2016 se practică reducerea deschisă și osteosinteza cu 2 broșe. Imobilizarea gipsată antebrahii palmară - digitală dreaptă. Evoluție favorabilă. și tratament medicamentos.

Evaluarea inițială- Stabilirea unui protocol de recuperare eficient a fost posibil doar în urma realizării unei evaluări inițiale complexe și eficiente. Această etapă a presupus evaluarea stării generale a subiectului, a mobilității articulare de la nivelul mâinii, a forței, a sensibilității și abilității mâinii.Pentru a realiza acestea a fost necesară aplicarea examenului fizic, bilanțului articular și a celui muscular. Odată cu evaluarea acestor parametrii s-a urmărit starea psihică și statusul nutrițional al subiectului.

Scala VAS - durerea subiectivă a persoanei suferinde

Aplicarea acestei scale ne oferă informații despre modul în care subiectul percepe durerea sa generală. Astfel putem observa eventualele tulburări de sensibilitate ale acestuia. 
Scor inițial $=7$; Scor final $=3$

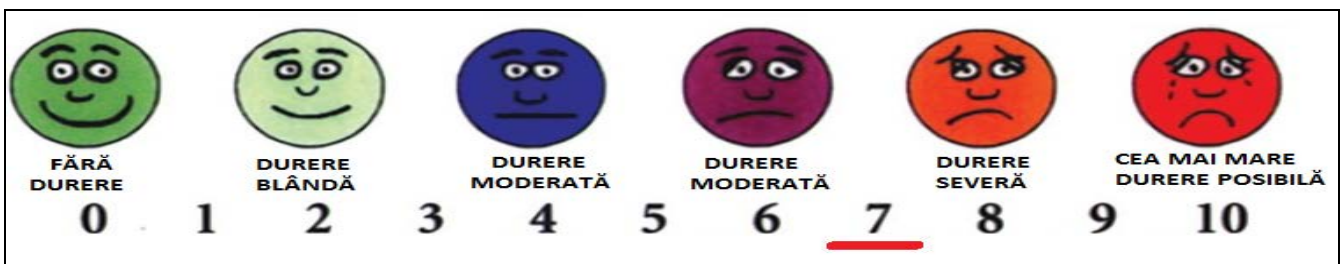

Figura1. Imaginea scalei VAS https://ro.pinterest.com/pin/

Observăm faptul că durerea resimțită de pacient la evaluarea inițială s-a diminuat foarte mult (aproximativ 5 puncte), acesta resimțind durerea doar în momentele de efort intens sau îndelungat.

Tabel 1 Bilanțul articular al pumnului efectuat cu ajutorul goniometrului

\begin{tabular}{|c|l|c|c|c|c|}
\hline \multirow{2}{*}{$\begin{array}{c}\text { Segmentul } \\
\text { mãsurat }\end{array}$} & \multirow{2}{*}{$\begin{array}{c}\text { Mișcarea } \\
\text { mãsuratã }\end{array}$} & $\begin{array}{c}\text { Membrul } \\
\text { drept }\end{array}$ & $\begin{array}{c}\text { Membrul } \\
\text { stâng }\end{array}$ & $\begin{array}{c}\text { Membrul } \\
\text { drept }\end{array}$ & $\begin{array}{c}\text { Membrul } \\
\text { stâng }\end{array}$ \\
\cline { 3 - 6 } & Flexie & $70^{\circ}$ & $90^{\circ}$ & $90^{\circ}$ & $90^{\circ}$ \\
\cline { 2 - 6 } & Extensie & $100^{\circ}$ & $170^{\circ}$ & $165^{\circ}$ & $170^{\circ}$ \\
\cline { 2 - 6 } & $\begin{array}{l}\text { Înclinare } \\
\text { Pudialã }\end{array}$ & $15^{\circ}$ & $30^{\circ}$ & $20^{\circ}$ & $20^{\circ}$ \\
\cline { 2 - 6 } & $\begin{array}{l}\text { Înclinare } \\
\text { cubitalã }\end{array}$ & $20^{\circ}$ & $45^{\circ}$ & $45^{\circ}$ & $45^{\circ}$ \\
\hline
\end{tabular}

Bilanţul articular - efectuat cu ajutorul goniometrului

Efectuarea bilanţului articular prin utilizarea goniometrului arată cu exactitate gradul de mișcare pe care subiectul este capabil să îl realizeze.

Tabel 2 Bilanțul articular al degetelor

\begin{tabular}{|c|c|c|c|c|c|c|c|c|c|c|c|}
\hline \multirow{3}{*}{$\begin{array}{c}\text { Segmentul } \\
\text { mãsurat }\end{array}$} & \multirow{3}{*}{$\begin{array}{l}\text { Mișcarea } \\
\text { mãsuratã }\end{array}$} & \multicolumn{5}{|c|}{ Membrul drept } & \multicolumn{5}{|c|}{ Membrul drept } \\
\hline & & \multicolumn{5}{|c|}{$\begin{array}{c}\text { Deget } \\
\text { Test initial }\end{array}$} & \multicolumn{5}{|c|}{$\begin{array}{c}\text { Deget } \\
\text { Test final }\end{array}$} \\
\hline & & I & II & III & IV & $\mathrm{V}$ & I & II & III & IV & $\mathrm{V}$ \\
\hline \multirow{2}{*}{ Deget } & Flexie & 70 & 70 & 70 & 50 & 40 & 7 & 70 & 70 & 70 & 70 \\
\hline & Extensie & 40 & 40 & 40 & 35 & 20 & $\begin{array}{l}4 \\
0\end{array}$ & 40 & 40 & 40 & 40 \\
\hline
\end{tabular}


Bilanțul muscular - efectuat prin aplicarea unor greutăți și cu ajutorul dinamometrului. Prin efectuarea bilanțului muscular observăm starea musculaturii și forța.

Tabel 3 Bilanțul muscular al pumnului realizat cu ajutorul opoziției puse de examinator

\begin{tabular}{|c|l|c|c|l|l|}
\hline \multirow{2}{*}{$\begin{array}{c}\text { Segmentul } \\
\text { mãsurat }\end{array}$} & \multicolumn{1}{|c|}{$\begin{array}{c}\text { Mișcarea } \\
\text { mãsuratã }\end{array}$} & $\begin{array}{c}\text { Membrul } \\
\text { drept }\end{array}$ & $\begin{array}{c}\text { Membrul } \\
\text { stâng }\end{array}$ & $\begin{array}{c}\text { Membrul } \\
\text { drept }\end{array}$ & $\begin{array}{c}\text { Membrul } \\
\text { stâng }\end{array}$ \\
\cline { 3 - 6 } & Flexie & F4 & F5 & F5 & F5 \\
\cline { 2 - 6 } & Extensie & F4 & F5 & F5 & F5 \\
\cline { 2 - 6 } Pumn & Înclinare radialã & F4 & F5 & F5 & F5 \\
\cline { 2 - 6 } & Înclinare cubitalã & F4 & F5 & F5 & F5 \\
\hline
\end{tabular}

Tabel 4 Evaluarea forței cu ajutorul dinamometrului

\begin{tabular}{|c|c|c|c|c|}
\hline \multirow{2}{*}{$\begin{array}{c}\text { Nivel de } \\
\text { dificultate }\end{array}$} & \multicolumn{2}{|c|}{ Test inipial } & \multicolumn{2}{c|}{ Test final } \\
\cline { 2 - 5 } & Membrul drept & Membrul stâng & $\begin{array}{c}\text { Membrul } \\
\text { drept }\end{array}$ & Membrul stâng \\
\hline I & 5 & 25 & 25 & 30 \\
\hline II & 5 & 20 & 20 & 25 \\
\hline III & 5 & 25 & 20 & 30 \\
\hline
\end{tabular}

Se observă în Tab. 4 creșterea forței musculare atât la nivelul membrului afectat cât și la nivelul celui sănătos. Forța musculară a înregistrat creșteri ce aproximativ 15 puncte nivelul mâinii drepte și de aproximativ 5 puncte la nivelul mâinii stângi.

Se observă din Tab.5 dificultatea în realizarea diferitelor tipuri de prehensiune cu degetul $\mathrm{V}$ precum și eliminarea acestei probleme și revenirea la capacitatea inițială de lucru la evaluarea finală.

Programul recuperator s-a desfășurat pe durata a trei luni; timp în care ședințele de recuperare s-au realizat în 5 zile pe săptămână în laboratorul de kinetoterapie. Pentru celelalte două zile subiectul a fost instruit și motivat să continue exerciţiile de kinetoterapie singur la domiciliu.

Pentru partea de încălzire analitică s-au folosit exerciții reprezentând mișcările fiziologice ale tuturor segmentelor corpului.

Pentru îndeplinirea obiectivelor propuse în programul de recuperare s-au folosit o serie de exerciții; acestea s-au realizat progresiv din punct de vedere al intensității și numărului de repetări, odată cu diminuarea simptomelor acestea crescând. 
Tabel 5 Scorul obținut prin aplicarea diferitelor tipuri de prehensiune

\begin{tabular}{|c|c|c|c|c|c|c|c|c|c|c|}
\hline \multirow{4}{*}{ Tipul de prehensiune } & \multicolumn{10}{|c|}{ Scor obținut $=56$} \\
\hline & \multicolumn{5}{|c|}{$\begin{array}{l}\text { Mânã dreaptã } \\
\text { Test inipial }\end{array}$} & \multicolumn{5}{|c|}{$\begin{array}{l}\text { Mânã dreaptã } \\
\text { Test final }\end{array}$} \\
\hline & \multicolumn{10}{|c|}{ Degete implicate în prehensiune } \\
\hline & I & II & III & IV & $\mathrm{V}$ & I & II & III & IV & $\mathrm{V}$ \\
\hline $\begin{array}{l}\text { Terminalã } \\
\text { (între vârful policelui și } \\
\text { vârful fiecãrui deget) }\end{array}$ & 1 & 1 & 1 & 1 & 1 & 1 & 1 & 1 & 1 & 1 \\
\hline $\begin{array}{l}\text { Subterminalã } \\
\text { (între „pulpa” policelui şi } \\
\text { „pulpa” altui deget) }\end{array}$ & 1 & 1 & 1 & 1 & 0 & 1 & 1 & 1 & 1 & 1 \\
\hline $\begin{array}{l}\text { Subtermino-lateralã } \\
\text { (între „pulpa” policelui și } \\
\text { partea lateralã a altui } \\
\text { deget) }\end{array}$ & 1 & 1 & 1 & 1 & 0 & 1 & 1 & 1 & 1 & 1 \\
\hline $\begin{array}{l}\text { Polici-digito-palmarã } \\
\text { (între palmã și ultimele } \\
\text { patru degete) }\end{array}$ & 1 & 1 & 1 & 1 & 0 & 1 & 1 & 1 & 1 & 1 \\
\hline $\begin{array}{l}\text { Opozitiie digito-palmarã } \\
\text { (ultimele patru degete și } \\
\text { palmã) }\end{array}$ & 1 & 1 & 1 & 1 & 0 & 1 & 1 & 1 & 1 & 1 \\
\hline $\begin{array}{l}\text { Latero-lateralã } \\
\text { (între fețele laterale ale } \\
\text { degetelor) }\end{array}$ & 1 & 1 & 1 & 1 & 1 & 1 & 1 & 1 & 1 & 1 \\
\hline
\end{tabular}

Exercițiile folosite în procesul recuperator au fost realizate utilizând poziții din cele mai comode (stând).

\begin{tabular}{|c|c|c|}
\hline \multicolumn{3}{|c|}{ PROGRAM DE RECUPERARE FRACTURÃ DE METACARPIAN V } \\
\hline CONTINUT & MIJLOACE & DOZARE \\
\hline \multicolumn{3}{|c|}{$\begin{array}{ll}\text { OBIECTIVE } \\
\text { - } & \text { reducerea gradului de durere pânã la dispariția totalã a acesteia; } \\
\text { - } & \text { reducerea gradului de inflamație pânã la dispariția totalã a acesteia; } \\
\text { - } & \text { menținerea funcției existente la începutul programului; } \\
\text { - } & \text { eliminarea stresului fizic și psihic al pacientului; } \\
\text { - } & \text { reducerea sensibilitãtii degetelor; } \\
\text { - } & \text { creșterea amplitudinii de mișcare de la nivelul pumnului și degetelor; } \\
\text { - } & \text { redobândirea forței musculare anterioare; } \\
\text { - } & \text { formarea reflexului de atitudine corectã a mâinii și degetelor; } \\
\text { - } & \text { refacerea funcționalitãtii mâinii, a coordonãrii dintre degete și a abilitãții; } \\
\text { - } & \text { reintegrarea în mediul social şi în muncã; } \\
\text { - } & \text { imbunătățirea și creșterea calității vieții subiectului. }\end{array}$} \\
\hline 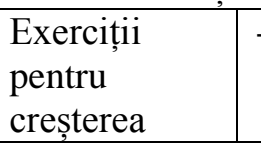 & $\begin{array}{l}\text { - din stand pe scaun, brațele relaxate, terapeutul } \\
\text { mobilizeazã pasiv fiecare articulaţie a degetelor și } \\
\text { pumnului (se începe distal de la falange și se terminã }\end{array}$ & $3 \mathrm{x}$ \\
\hline
\end{tabular}




\begin{tabular}{|c|c|c|}
\hline $\begin{array}{l}\text { mobilitãții de } \\
\text { mișcare }\end{array}$ & $\begin{array}{l}\text { proximal la nivelul oaselor carpiene); } \\
\text { - din stand pe scaun, brațele relaxate, se mobilizeazã } \\
\text { activo - pasiv fiecare articulație a degetelor și } \\
\text { pumnului; } \\
\text { - din stand pe scaun, brațele relaxate, subiectul își } \\
\text { mobilizeazã activo fiecare articulație a degetelor și } \\
\text { pumnului (terapeutul supravegheazã permanent } \\
\text { tehnica de execuție); } \\
\text { - din stand pe scaun, brațele relaxate coatele lipite de } \\
\text { trunchi, palmele orientate în sus, policele atinge } \\
\text { fiecare vârf al celorlalte patru degete; } \\
\text { - din stand pe scaun, brațele relaxate coatele lipite de } \\
\text { trunchi, palmele fațã în fațã se ating degetele } \\
\text { corespondente de la fiecare mânã; } \\
\text { - din stand pe scaun, brațele relaxate, terapeutul } \\
\text { mobilizeazã pasiv fiecare articulație a degetelor și } \\
\text { pumnului (se începe distal de la falange și se terminã } \\
\text { proximal la nivelul oaselor carpiene); } \\
\text { - din stand pe scaun, brațele relaxate, se mobilizeazã } \\
\text { activo - pasiv fiecare articulație a degetelor și } \\
\text { pumnului; } \\
\text { - din stand pe scaun, brațele relaxate, subiectul își } \\
\text { mobilizeazã activo fiecare articulație a degetelor și } \\
\text { pumnului (terapeutul supravegheazã permanent } \\
\text { tehnica de execuție); } \\
\text { - din stand pe scaun, brațele relaxate coatele lipite de } \\
\text { trunchi, palmele orientate în sus, policele atinge } \\
\text { fiecare vârf al celorlalte patru degete. } \\
\text { - din stand pe scaun, brațele relaxate coatele lipite de } \\
\text { trunchi, palmele fațã în fațã se ating degetele } \\
\text { corespondente de la fiecare mânã; } \\
\text { - din stand pe scaun, brațele relaxate coatele lipite de } \\
\text { trunchi, palmele lipite se realizeazã abducția și } \\
\text { adducția degetelor concomitent cu mișcarea de } \\
\text { înclinare radialã și cubitalã; } \\
\text { - diagonalele Kabbat pentru membrele superioare, } \\
\text { flexie și extensie. }\end{array}$ & \\
\hline $\begin{array}{l}\text { Exerciții } \\
\text { pentru } \\
\text { recâștigarea } \\
\text { forței }\end{array}$ & $\begin{array}{l}\text { - din stând pe scaun, brațele relaxate coatele lipite de } \\
\text { trunchi, palma orientatã în sus cu degetele întinse, } \\
\text { subiectul realizeazã mișcarea de flexie a mâinii } \\
\text { împotriva rezistenței puse de terapeut; } \\
\text { - din stând pe scaun, brațele relaxate coatele lipite de } \\
\text { trunchi, palma orientatã în jos cu degetele întinse, } \\
\text { subiectul realizeazã extensie de flexie a mâinii } \\
\text { împotriva rezistenței puse de terapeut; } \\
\text { - din stând pe scaun, brațele relaxate coatele lipite de } \\
\text { trunchi, palma orientatã în lateral cu degetele întinse, } \\
\text { subiectul realizeazã mișcarea de înclinare }\end{array}$ & $2 x$ \\
\hline
\end{tabular}




\begin{tabular}{|c|c|c|}
\hline & $\begin{array}{l}\text { radialã/cubitalã a mâinii împotriva rezistenței puse de } \\
\text { terapeut; } \\
\text { - din stând pe scaun, brațele întinse cu palmele în } \\
\text { supinație se executã flexia și extensia degetelor în } \\
\text { palmã având în palmã o minge de burette; } \\
\text { - din stând pe scaun, brațele relaxate coatele lipite de } \\
\text { trunchi, palmele orientate în sus ținând un prosop în } \\
\text { ambele; se încearcã strângerea prosopului cu } \\
\text { menținerea poziției pentru câteva secunde; } \\
\text { - din stând pe scaun, brațele pe lângã corp având o barã } \\
\text { de cauciuc (sau un prosop) se încearcã ”stoarcerea” } \\
\text { acestuia cu menținerea poziților finale; } \\
\text { - din stând depãrtat cu fața la spalier având o bandã } \\
\text { elasticã în palmã se executã mișcarea triplei flexii a } \\
\text { membrului superior urmatã de extensia acesteia } \\
\text { (flexia mâinii pe antebraț, flexia antebrațului pe braț și } \\
\text { flexia brațului). }\end{array}$ & \\
\hline $\begin{array}{l}\text { Exerciții } \\
\text { pentru } \\
\text { reeducarea } \\
\text { abilitãții }\end{array}$ & $\begin{array}{l}\text { - din stând pe scaun, coatele sprijinite pe masã, palmele } \\
\text { în supinație subiectul executã mișcãrile de } \\
\text { prehensiune; } \\
\text { - din stând pe scaun, brațele orientate spre înainte } \\
\text { subiectul realizeazã mișcãrile de prehensiune cu } \\
\text { prinderea unor diferite obiecte și menținerea acestora } \\
\text { pentru } 5 \text { secunde; } \\
\text { - din stând cu fața la perete orientat spre „placa } \\
\text { canadianã” subiectul realizeazã mișcãrile de } \\
\text { prehensiune concomitent cu tragerea, ținerea sau } \\
\text { legarea diferitelor obiecte; } \\
\text { - din stând cu fața spre masã subiectul transportã mâna } \\
\text { afectatã diferite obiecte de pe masã într-o ladã. }\end{array}$ & $4 x$ \\
\hline $\begin{array}{l}\text { Electro- } \\
\text { terapia }\end{array}$ & $\begin{array}{l}\text { - pentru a combate durerea existentã precum și } \\
\text { inflamația și pentru a permite realizarea exercițiilor de } \\
\text { kinetoterapie la o intensitate mai mare s-au folosit o } \\
\text { serie de curenți electrici; } \\
\text { - pentru aceasta s-au folosit curenții TENS și } \\
\text { Diadinamic; } \\
\text { - curentul TENS (stimulare electricã trans cutanatã) s-a } \\
\text { folosit în scopul diminuãrii durerii fiind eficient în } \\
\text { cazurile post traumatice. Intensitatea curentului fiind } \\
\text { oscilantã în funcție de starea fizicã a subiectului; } \\
\text { - curentul Diadinamic Perioadã Lungã (PL) a fost } \\
\text { utilizat pentru a rolul sãu în combaterea redorii } \\
\text { articulare instalate în timpul mobilizãrii. Totodatã } \\
\text { acest tip de curent a adus un efect antalgic și } \\
\text { miorelaxant de o intensitate moderatã la nivelul } \\
\text { palmei. }\end{array}$ & $\begin{array}{l}10 \\
10 \\
\text { minute }\end{array}$ \\
\hline
\end{tabular}


Exercițiile utilizate au avut pe lângă rolul de a recupera o anumită calitate a mâinii şi rolul de a obișnui și reeduca mâna pentru a realiza sarcinile zilnice și activitățile specifice acesteia.

\section{Rezultate şi discuţii}

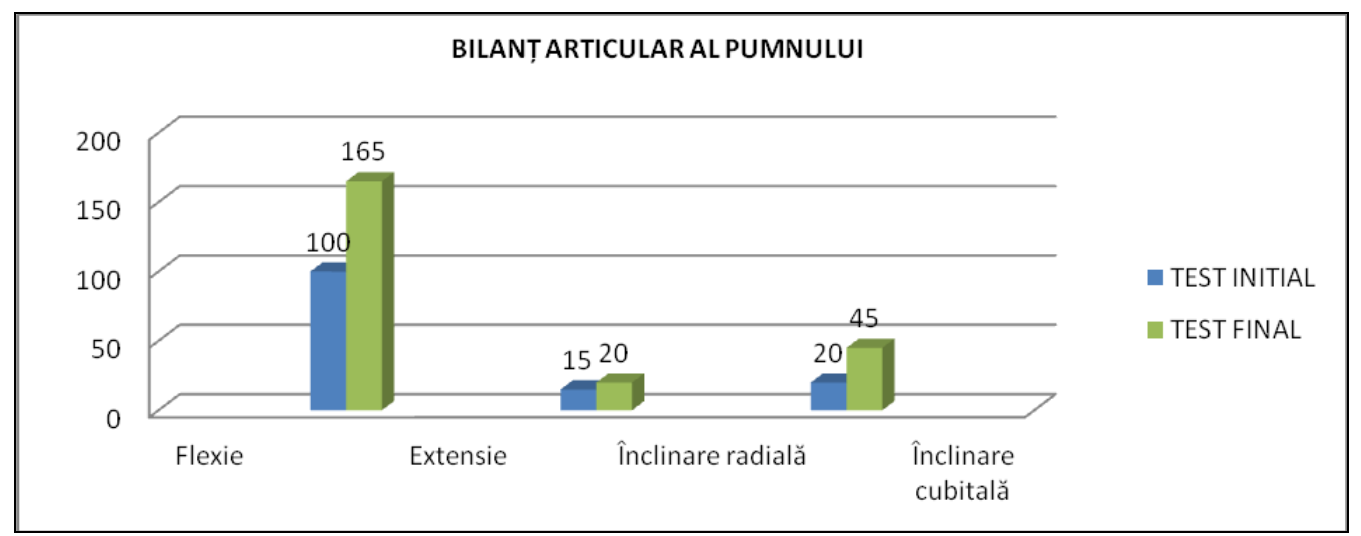

Figura 1. Rezultatele obținute în urma aplicării bilanțului articular la nivelul pumnului

Se observă faptul că amplitudinea de mișcare redusă de la nivelul pumnului drept a crescut, valorile sale fiind foarte apropiate de cele normale înregistrate la nivelul pumnului stâng.

La nivelul pumnului stâng valorile normale s-au menținut la valoarea normală, creșterea amplitudinii de mișcare înregistrându-se la mișcarea de înclinare cubitală.

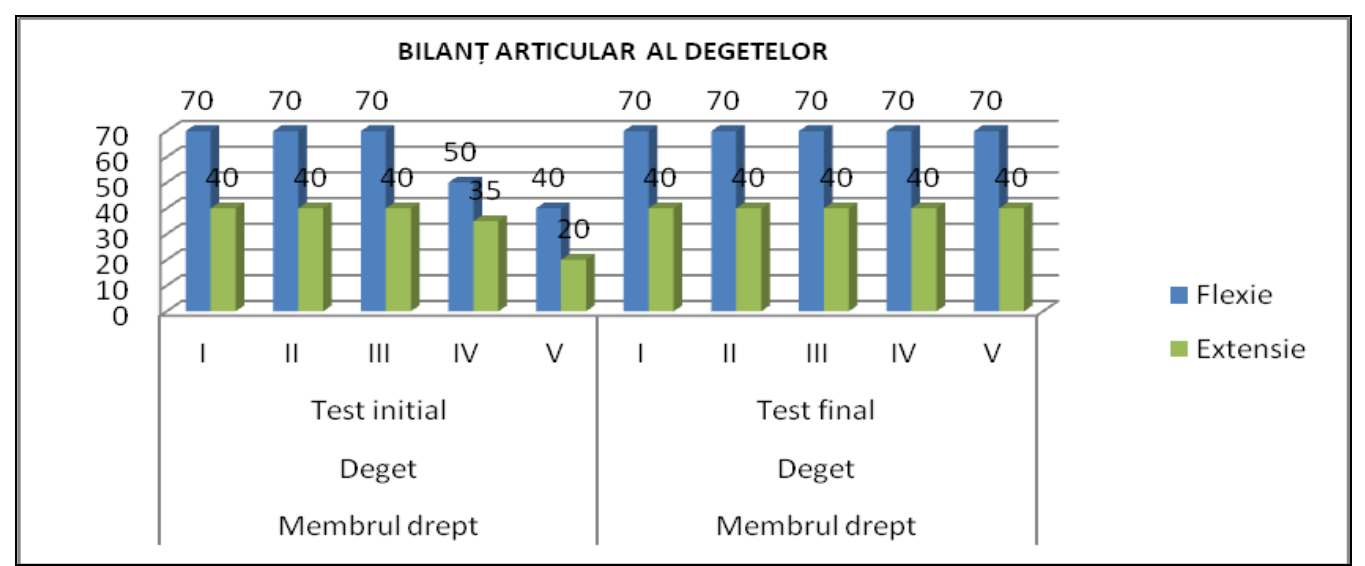

Figura 2. Rezultatele obținute în urma aplicării bilanțului articular la nivelul degetelor 
Se observă creșterea forței musculare a mâinii drepte pe toate mișcările (de la 4 la 5), astfel forța devenind normală și egală cu mâna stângă.

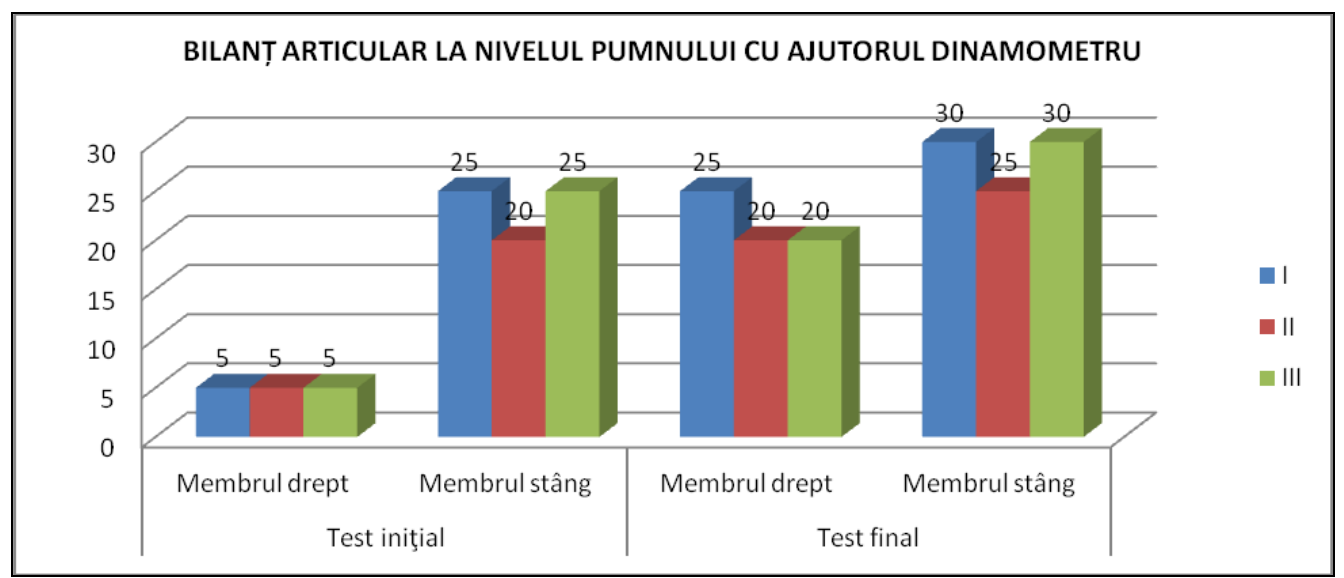

Figura 3. Rezultatele obținute în urma aplicării bilanțului muscular la nivelul pumnului cu ajutorul dinamometrului

Se observă creșterea forței înregistrate cu ajutorul dinamometrului cu arc.

Prin utilizarea dinamometrului cu arc a fost posibilă măsurarea forței palmare din trei poziții diferite, prin depărtarea sau apropierea mânerului. Nivelele au avut o dificultate diferită, forța necesară pentru a acționa dinamometrul fiind mai mare la nivelul I mergând descrescător până la nivelul III.

\section{Concluzii}

- Ipoteza a fost confirmată.

- Această lucrare poate fi folosită pentru a realiza un studiu aprofundat asupra acestui tip de traumatism.

- Buna colaborare a pacientului cu kinetoterapeutul reprezintă un factor important în reuşita recuperării;

- Buna informare a pacientului, motivarea acestuia, lucrul său conștient și încrederea sunt idealuri pe care kinetoterapeutul trebuie să le atingă;

- Lucrul la domiciliu, continuarea recuperării și protejarea zonei lezate o perioadă mai lungă de timp (aproximativ 6 luni) sunt necesare pentru menținerea rezultatelor obișnuite. 